\title{
POSSIBLE FUTURES: COVID-19 AS HISTORICAL TURNING POINT
}

Possíveis futuros: COVID-19 como ponto de inflexão histórico

Posibles futuros: COVID-19 como punto de inflección histórico

DOI: https://doi.org/10.1590/S2178-149420210210

'Dartmouth College - Hanover (NH), United States.

*Lecturer in Latin American Studies and History (andre.rd.pagliarini@dartmouth.edu).

(D) https://orcid.org/0000-0002-0443-0177

Article received on January 1, 2021 and approved for publication on March 23, 2021. 


\begin{abstract}
This article surveys the ways that the global COVID-19 pandemic has effected higher education in the United States. After reviewing the effects of this critically important historical episode on colleges, particularly as it pertains to the humanities, I outline potential paths forward in the years to come. The fundamental tension I highlight is that between returning to a pre-COVID status quo or imagining an alternative model that is ultimately more sustainable for students and academics alike.
\end{abstract}

KEYWORDS: COVID-19; Higher Education; Liberal Arts; Social Media; Shock Doctrine.

\title{
Resumo
}

Este artigo analisa as maneiras como a pandemia afetou o ensino superior nos Estados Unidos. Depois de revisar os efeitos desse episódio histórico e criticamente importante para as faculdades, particularmente no que diz respeito às humanas, delineio caminhos que poderão se desdobrar nos próximos anos. A tensão fundamental que destaco é aquela entre retornar a um status quo pré-COVID ou imaginar um modelo alternativo que seja, em última análise, mais sustentável para alunos e professores.

PALAVRAS-CHAVE: COVID-19; Ensino Superior; Humanas; Mídia Social; Doutrina de Choque.

\section{RESUMEN}

Este artículo analiza las formas en que la pandemia ha afectado la educación superior en los Estados Unidos. Después de revisar los efectos de este episodio histórico y de importancia crítica para las facultades, particularmente en lo que respecta a las humanas, esbozo los caminos que pueden abrirse en los próximos años. La tensión fundamental que destaco es la que hay entre volver a un status quo anterior a COVID o imaginar un modelo alternativo que, en última instancia, sea más sostenible para estudiantes y profesores.

PALABRAS CLAVE: COVID-19; Educación Superior; Humanas; Redes Sociales; Doctrina del Shock. 
ssociate Deans (@ass_deans) is a parody account on Twitter that satirizes the arcane bureaucracy of higher education in the United States. The COVID-19 pandemic has provided them with plenty of material. "Now that we have the videos of your lectures," reads a tweet from March 1st, 2021, "we don't really need you. Thanks for your service!". The question of how COVID-19 will reshape higher education not to mention life beyond academia — is still open and, for that reason, uncomfortable. As the once-reliable professional prospects of academics erode, so do protections and benefits for workers in other sectors of the economy, the bitter fruit of corporate-friendly anti-union policies planted and assiduously maintained in most states for years. One possibility is that colleges, many of which found themselves in alarming fiscal straits even before the pandemic, will tighten their embrace of cost-saving measures like hiring more adjunct instructors and offering fewer tenure-track positions (this is the sort of professional precariousness that Associate Deans joked about in the tweet mentioned above). Another possibility is that higher education institutions will emerge from this treacherous situation with a renewed commitment to building solid institutions, investing in the people and physical spaces that defined academic pursuits prior to the jarring disruption of the novel coronavirus.

These are not the only roads on the horizon, of course, but posing the contrast in such stark terms is useful in clarifying the stakes of what happens next. Will things largely go back to the way they were once COVID is contained or will the changes we have all been forced to make in our daily lives over the past year and a half prompt lasting shifts in the way we organize our professional lives and, by extension, our political, economic, and social behaviors? In this essay, various overlapping threads in this ongoing debate will be addressed, beginning with institutions of higher education before taking a broader perspective on the future of work. The goal was not to argue decisively in one direction or another, but to offer an overview of the possible futures to come in a post-pandemic world. In short, the merits of considering this period as a historical turning point were assessed.

More than anyone, historians must be humble about predictions. As Kim Sterelny put it, "academic historians have a deep professional distrust of attempts to say what would have happened if, say, the Persian fleet had been victorious at Salamis." This is because "historians produce causal analyses, not chronicles, of historical trajectories" (Sterelny, 2016: 525). It is impossible to know what would have happened if COVID-19 had not emerged when it did (might Donald Trump have won reelection?). The future is equally unknowable. What we can do, however, is to think historically about what is possible, and perhaps even likely, 
in the wake of momentous events like global pandemics. In her influential 2007 book, The shock doctrine: the rise of disaster capitalism, Naomi Klein discussed several examples of "orchestrated raids on the public sphere in the wake of catastrophic events, combined with the treatment of disasters as exciting market opportunities" (Klein, 2007: 6). Whether she might include the current pandemic in a future edition of the book remains to be seen. It is not too soon to ask such questions.

\section{THE COMORBIDITY OF HIGHER EDUCATION}

F irst, the good news: despite apocalyptic prognoses made during the early days of the lockdown, U.S. institutions of higher education have not been forced to permanently close on a massive scale. Small colleges have been disproportionately harmed by the sudden inability to welcome students in person. Most recently, Becker College, founded in 1784 in Worcester, Massachusetts, announced it might not be able to reopen ever again. Citing the pandemic as a contributing factor in its demise, Becker joins a list of private, nonprofit colleges forced to shutter for good, including Holy Family College in Wisconsin; MacMurray College in Illinois; Concordia College in New York; and Pine Manor College in Massachusetts. Despite these closures, most institutions have managed to weather the storm for the simple reason that individual investment in a college degree is still widely seen as critical to succeeding in the competitive economy of the twenty-first century. The pandemic has not been so disruptive as to alter the basic meritocratic assumptions of modern globalization.

As Rebecca S. Natow notes, however, "the academy is becoming a more frugal employer, a more virtual entity, and less of a home to the traditional liberal arts" (Natow, 2021). This slow-motion transformation represents an identity crisis for the American academy. After all, as students worried about a cut-throat job market flock to majors in STEM fields, colleges across the country have seen fit to chip away at a traditional pillar of higher education liberal arts. Indeed, majors like English, History, Philosophy, Anthropology, Music, and the like have struggled to attract students pursuing degrees that are supposedly more marketable. The University of Alaska system, for example, announced plans to cut 39 academic departments, including fields like chemistry and earth science, in addition to numerous liberal arts programs. Similarly, the College of Saint Rose in New York will eliminate 16 majors and six master's degrees. Dartmouth College laid off or cut back the hours of almost 30 workers (this author is one of the lucky contingent instructors to have been retained throughout the pandemic). Overall, Dartmouth projects an \$83 million deficit for fiscal year 2021. As Anne Dennon reports, "so far, over 50 doctoral programs in the humanities and social sciences 
have decided to refrain from admitting new students for fall 2021" (Dennon, 2021). Nervous administrators justified these drastic measures by arguing that the funds that would have been awarded to prospective new students in admissions packages would instead be used to keep current students on track amid the disruption of the pandemic. But, looking ahead, analysts of graduate education worry that, in the United States, frozen admissions, curtailed graduate cohorts, and frozen research projects could put a lasting squeeze on the ranks of professional researchers for at least the short term, and maybe longer (Zahneis, 2021). "As alumni mourn the loss of their degree programs," Dennon concludes, "current students must decide whether to change majors - or even schools — during one of higher education's hardest years" (Dennon, 2021).

To be sure, the trend Natow identifies reinforces patterns already observable before the pandemic. Colleges committed to resisting austerity in response to COVID-19 find themselves dealing with preexisting structural issues like demographic decline and the increasing reluctance of students and parents to take on considerable debt to finance higher education. As Michael T. Nietzel observed in October 2020, small, private colleges confront a particular set of circumstances that make the financial impact of the pandemic especially grievous. "First," he notes, "with the exception of those schools with large endowments, small residential colleges have fewer sources of revenue than larger schools. Consequently they depend to a greater extent on tuition and room and board fees, both of which have been plunging this semester." Indeed, some parents even resorted to taking legal action against colleges to extricate themselves from their commitment to paying tuition. Second, Nietzel points out that "early indicators are that private colleges are suffering larger enrollment dips than public universities. Undergraduate numbers at private, nonprofit four-year institutions have declined 3.8\% this semester, compared to public four-year institutions with a slight decrease of $0.4 \%$. And finally, small colleges continue to try to cope with students' flight from the humanities, requiring them to reevaluate and possibly retool the very curricula that historically have been their calling card and that have been the main province of their senior faculty" (Nietzel, 2020). These factors represent a comorbidity for higher education in the face of the pandemic.

Will the improvisational nature of instruction under the shadow of COVID-19 push administrators to recognize the importance of investing in quality in-person instruction for students? This is not to say that virtual education should be abolished or that there are not important pedagogical lessons to glean from this experiment, but it is clear that something essential about the learning process does not translate remotely. As Anna Kornbluh put it, "face-to-face learning is irreplaceable - even in a virtualizing culture, even when classroom 
infrastructures are overcrowded and outmoded, even when administration has become the dominant sector in education" (Kornbluh, 2020). Administrators will have to weigh thriftiness against the quality of instruction.

If the way students are taught is permanently altered, so should be the expectations and demands made on instructors. For one thing, as Kornbluh argues, "we cannot willingly contribute to the rebranding of education as 'content delivery, '" a discursive shift that pushes the courses carefully created and curated by experts in their respective fields to the same plane as disposable entertainment products so readily accessible. Institutions of higher education must commit to not monetizing the work of instructors beyond the bounds of education. Online instruction has the potential to generate new forms of surveillance and commerce. Administrators must leave that door firmly shut.

The way faculty is evaluated by their institutions should also be reconsidered. For example, performance reviews, which often determine whether contingent faculty will be rehired on a year-to-year basis, should be reformatted to account for the anomalous year and a half that has just been endured. After all, conferences and guest lectures have been canceled, publications delayed, and alternate teaching strenuously improvised. Student evaluations should not be proctored or employed as usual. Without strict administrative commitments to resuming ordinary instruction after the pandemic eases, and in the presence of administrative memos specifying "indefinite" and "permanent" dimensions of the transition, instructors must recognize the power they have - albeit limited by several structural factors - to shape events going forward. Upheaval presents an opening for reinvention. Historically, this pattern has not favored workers, but, as Kornbluh notes, "faculty are a creative lot who should be able to anticipate and deflect the risks of coronavirus shock doctrine." She pushes the bounds of the possible even further, arguing that:

We must seize this moment to organize for student debt relief, student and faculty health care, and the public goods of research and expertise. Tasked with conjuring continuity in a pandemic, we find ourselves at a precipice that clarifies how much we have overworked to weather the structural adjustment of higher ed, and how much we have in common with each other — with the hourly employees who make the university and its surrounding businesses go, with our students, with the school teachers who've been struggling and striking nationwide. A cataclysm is here. What can we collectively rebuild? (Kornbluh, 2020)

Instructors and other critical components of the machinery of higher education must not allow themselves to be passively worked over. The job market was bleak even before the pandemic. It will take collective investment and commitment to ensure there is a future for all of us in this noble profession. 


\section{THE LONG-TERM EFFECTS OF THE PANDEMIC ON THE "REAL WORLD"}

7 hose enmeshed in college campuses are used to hearing references to the so-called "real 1 world," that is, the competitive, cutthroat professional rat race that exists beyond the walls of the academy (as if the ranks of higher education were not filled with ambitious personalities and big egos). Much has already been written on the medium to long-term effects of the current pandemic on issues ranging from global politics to individual relations. The question of whether the last year and a half constitutes a historic turning point will continue to be debated for many years to come. As Kwasi Konadu wrote in a recent discussion of the pandemic's historic implications, "COVID-19 is both global and local, and so our perspectives must be attentive to global patterns and local consequences and responses" (Konadu, 2020: 115). Given their practice of adjudicating causality across time and space, historians have an important role to play in such reflections going forward.

The most salient historical parallel that has emerged in analyses of the novel coronavirus is the influenza pandemic of 1918-19. Perhaps unsurprisingly, Jeremy Brown's 2018 book, Influenza: the hundred-year hunt to cure the 1918 Spanish flu pandemic, became a bestseller. As Brown writes in the introduction to that history so urgently relevant all of a sudden, "just one century is all that separates us from a global health crisis that killed more people than any other illness in recorded history. What we've learned in the interim is enough to scare and motivate us, but maybe not enough to stop another pandemic from happening" (Brown, 2018: 7). Indeed, that global health crisis, which infected half a billion people and killed twice the number of soldiers in combat and more than all the soldiers and citizens who died in the war, long sat in the shadow of World War I in our collective historical memory. Although people die in war as combatants and unintended casualties, Konadu reminds us that war is a human endeavor: "The causes and consequences of war are not located in nature nor a laboratory or a market of human-animal proximity, where diseases jump from one specie to another. COVID-19 is different from war; it is an event because the world knows about it and the response is global" (Konadu, 2020: 116).

The history of how the 1918 pandemic unfolded in Brazil, as recounted in a new book by Lilia M. Schwarcz and Heloisa M. Starling, is tragically resonant today. In the early twentieth century, the so-called Spanish Flu, a particularly lethal H1N1 mutation, arrived in Brazil on board ships coming from Europe. The subsequent pandemic paralyzed the economy and exposed the precariousness of the nation's health services. The pandemic killed tens of thousands all over Brazil and about 50 million worldwide. Political disputes and denialist attitudes by politicians and doctors — not to mention medical ignorance of the new disease - made 
matters worse. Then, as now, the poorest members of society bore the brunt of the state's mismanagement. Riven by fake or faulty statistics and useless miracle cures, the population remained at the mercy of the virus until the epidemic's sudden decline in early 1919. "There was no national permanent coordinated action in the field of public health to attend to a country that entered the first decades of the twentieth century in poor health," Schwarcz and Starling write, framing the pandemic as a critical test of the nation's capabilities - one that the nascent republic utterly failed (Schwarcz and Starling, 2020: 19).

Today, of course, there is a robust set of institutions catering to public health at international and national levels. How then to explain the failure of governments to prepare for an event like the COVID-19 pandemic? What does it mean for international relations going forward? If anything, the response to the current global health crisis seems to have fortified several existing political dynamics in ways that suggest the future will not be radically different from the pre-pandemic status quo. In response to COVID-19, governments at every level in the United States and around the world implemented significant short-term interventions in the form of lockdowns, increased insurance payments, direct subsidies to encourage people to stay home, and new economic regulations. These were generally framed as temporary emergency measures rather than the bases for a new long-term socioeconomic foundation. It did not seem to take long for political tribalisms to reassert themselves in the realm of public policy. Political polarization likely placed any lasting change in the relationship between society and the state out of reach.

Broadly speaking, the policy disputes that have raged since the early days of the pandemic "are a proxy in the larger struggle over the meaning of liberalism, both as ideology and as governance," according to Anthony Gregory (2020: 4). In the United States, a conspiratorial, anti-scientific strain quickly consumed much of the Republican Party, one of the two main political parties. Aggressive measures like lockdowns and mask mandates were added to the list of examples of supposed government overreach and attacks on individual freedom. Owing much to the rhetoric of then-President Donald Trump, this attitude spread across much of the world, perhaps most calamitously in Brazil. While political voices from the center-right to the far-left have championed state mobilization guided by science, others have blamed overbearing government for ruining the finances of poor and working-class families, framing the pandemic response as a choice between economic growth and collapse.

But if 2020 was a disastrous year for the United States, Brazil, and most of the planet, the long-term implications of COVID-19 for the United States' position as global hegemon do not appear to be decisive. In other words, it does not seem like the pandemic has shifted the global balance of power, at least no more so than other factors shaping the possible futures 
that await us. There have been no significant impacts to American military readiness, for example, no bases have been shuttered. It is possible that the economic impacts of COVID-19 could potentially hinder the long-term health of the American economy, but, as Emma Ashford points out, this is far from a foregone conclusion (Ashford, 2020). What the COVID crisis has done is highlight existing trends with the potential to undermine American power, notably political polarization and domestic underinvestment. The same is true in countries like Brazil, where the federal government's pathetic response to the pandemic has only highlighted the precariousness of the country's public health infrastructure and its uneven ability to care for all of its citizens.

Despite rhetorical and political shortcomings, it is true that most major countries spent considerably to mitigate against the worst economic effects of the pandemic. The austerity economics that have consumed so much political energy in the wake of the 2008 global financial crash was immediately displaced. Its return is one possible future. For now, however, major government spending is back with heretofore unthinkable interventions from even conservative governments. As David Hulme and Rory Horner point out:

The initial pressures for these transformations focused on proximate problems: rapid responses to risks of premature death from a new disease and temporary support for employment, incomes, household food security and the economy. But, at a structural level, the coronavirus pandemic could help transform the institutions and norms that have underpinned global development in the early $21^{\text {st }}$ century, for better or worse (Hulme and Horner, 2020: 183).

Indeed, Hulme and Horner imagine a possible future very different from the pre-pandemic status quo, ultimately concluding, however, that "that the world will 'recover' from COVID-19 but back to the bad scenario" (Hulme and Horner, 2020: 190). What is the bad scenario they discuss? It is a global situation marked by unsustainability and inequality - in essence, the world before COVID-19 reared its head. "While this would mean historically 'high' levels of human development and relatively 'low' levels of absolute poverty," they note, asserting that pre-lockdown conviviality seems good compared to the social isolation we are all enduring now, "a return to this situation is 'bad' as it means that climate crisis, and stark and rising within-country inequality, continue" (Hulme and Horner, 2020: 186).

But Hulme and Horner also outline what a positive outcome could look like, one worth considering in a survey of possible post-pandemic futures. This involves structural shifts toward more generous and nimble institutions of national and transnational governance. They argue that there is historical precedent for optimism. The Black Death of the fourteenth century (a much more severe pandemic that reduced Europe's population by 30 to 60 per cent) is credited by 
many historians with causing the critical labor shortage that ultimately gave peasants and workers a stronger hand in advocating for their interests. This kicked off political processes that would lead to the evolution of more democratic political institutions and norms over ensuing centuries. The calamitous world wars of the twentieth century fostered forms of capitalism that shared the growing wealth of industrialized countries more equitably across their societies than in the pre1919 world (here, interestingly, they cite the work of Thomas Pikkety to note the trends of income redistribution that followed the carnage of modern industrial warfare). This led to higher incomes and improved levels of human development across Europe, North America, and elsewhere as greater public investment in education, health, social housing, and welfare improved the lives of tens of millions of people. "This idea of a negative 'event' creating longer-term positive effects has become a rallying call for progressive policy change or sociopolitical structural transformation," the authors observe. They imagine this brighter scenario as one less dependent on any one country for assistance. A rising tide lifting capable, committed governments everywhere, in other words: "Global governance initiatives this century have struggled to deal with a more multi-polar world, but this crisis could act as a catalyst to re-energize international cooperation (not just in health) without US leadership" (Hulme and Horner, 2020: 188).

Furthermore, coordinated efforts to contain the pandemic could lead to stronger cooperation not just in health but also in tackling climate change and inequality going forward. The crises of climate change and COVID-19 can and should be confronted together. Indeed, it should not surprise us that the most disastrous responses to the pandemic have come from the same forces who resist the science of climate change. Denialism in one critical area bleeds into another, costing lives and collective prosperity. The pandemic has demonstrated that public health depends on the well-being of the most vulnerable, strengthening the case for universal health coverage in places where it does not exist (the United States, for example, the wealthiest country in the history of the world, does not guarantee health care to all its citizens) and for further investment in places with underfunded national health systems (Brazil, most notably). Any serious effort to reckon with the devastation wrought by COVID-19 will lead one to the host of preexisting issues highlighted by the pandemic. If coronavirus proves to be the impetus needed to attack these deep structural problems, it will have done at least some good.

\section{CONCLUSION}

Then future historians look back on the COVID-19 pandemic, they will surely weigh
the ways it disrupted and reinforced existing norms of sociability, work, economic organization, and political fragmentation. Less clear is whether they will consider the public 
health crisis a genuine turning point in the twenty-first century. Will the years to come be defined by the resurgence of austerity, which fueled populist politics on the left and right around the world along with growing disillusion with democracy itself or will it rekindle popular aspirations for a more generous, more forward-thinking government that places the basic needs of all its citizens above the interests of a powerful entrenched minority? This is the main drama unfolding before our eyes. We are the historical actors that historians in the future will look to in order to understand why events unfolded the way they did. This, it goes without saying, is an enormously empowering idea.

We are just starting to grasp the impact of COVID-19 on the global social and political order. Lockdowns have kept people cooped up at home, generally unable or unwilling to take to the streets when they might otherwise have done so. The pandemic's effects on public protest and social movements thus remains obscure (Pinckney and Miranda Rivers, 2020). While it has certainly disrupted the preexisting flow of political debate and confrontation, the COVID-19 pandemic has not led to a suspension of political conflict. It has been a phase of revelation and intensification of social strains, in which social inequalities have become more evident and institutional responsibilities in the overall management of society more apparent (Gerbaudo, 2020: 73). Considering the damaged state of the global economy and growing social discontent, the bottled-up tendencies produced by the pandemic may well provoke far-reaching changes in the year to come. It is hard to imagine such disruption having few lasting consequences. Vast historical changes have been prompted by far less in the past.

Conflicts of interest: none.

Funding: none.

\section{REFERENCES}

ASHFORD, E. The Aftermath: American Power after COVID-19. Istituto Affari Internazionali (IAI)-IAI Papers, v. 2, n. 35, 2020.

BROWN, J. Influenza: the hundred-year hunt to cure the 1918 Spanish flu pandemic. New York: Atria, 2018.

DENNON, A. Colleges cut liberal arts majors due to COVID-19. Best Colleges, 2021. Available at: <https:// www.bestcolleges.com/blog/colleges-cut-liberal-arts-majors-covid-19/>. Accessed on: 2021 Feb. 16.

GREGORY, A. The American Revolution that Wasn't. Istituto Affari Internazionali (IAI)-IAI Papers, v. 2, n. 35, 2020. 
HULME, D.; HORNER, R. After the immediate coronavirus crisis: three scenarios for global development. In: CARMODY, P. et al. (eds.). COVID-19 in the global south: impacts and responses. Bristol: Bristol University Press, 2020. p. 183-192.

GERBAUDO, P. The pandemic crowd: protest in the time of COVID-19. Journal of International Affairs, New York, v. 73, n. 2, 2020.

KLEIN, N. The shock doctrine: the rise of disaster capitalism. New York: Metropolitan Books/Henry Holt and Company, 2007.

KONADU, K. COVID-19 and caution for historians: views from a place in West Africa. Journal of West African History, East Lansing, v. 6, n. 2, p. 1-4, 2020. https://doi.org/10.14321/jwestafrihist.6.2.fm

KORNBLUH, A. Academe's coronavirus shock doctrine: faculty members are already stretched thin, and now they are being asked to do more. They should hesitate before doing so. The Chronicle of Higher Education, 2020. Available at: <https://www.chronicle.com/article/academes-coronavirus-shock-doctrine/>. Accessed on: 20xx Mon Day.

PINCKNEY, J.; RIVERS, M. Sickness or silence: social movement adaptation to COVID-19. Journal of International Affairs, New York, v. 73, n. 2, p. 1-20, 2020.

NATOW, R. Why haven't more colleges closed? Prognosticators predicted mass shutterings. That hasn't happened, but other enormous changes are underway. The Chronicle of Higher Education, 2021. Available at: $<$ https://www.chronicle.com/article/why-havent-more-colleges-closed>. Accessed on: 2021 Mar. 10.

NIETZEL, M. T. Liberal arts colleges face the full force of the pandemic. Forbes, 2020. Available at: $<$ https://www.forbes.com/sites/michaeltnietzel/2020/10/07/liberal-arts-colleges-face-the-full-force-of-thepandemic/?sh=6d8330bc1938>. Accessed on: 20xx Mon Day.

SCHWARCZ, L. M.; STARLING, H. M. A bailarina da morte: a gripe espanhola no Brasil. São Paulo: Companhia das Letras, 2020.

STERELNY, K. Contingency and history. Philosophy of Science, Chicago, v. 83, n. 4, 2016.

ZAHNEIS, M. The Shrinking of the Scholarly Ranks The pandemic may do lasting damage to the pipeline of academic researchers. The Chronicle of Higher Education, 2021. Available at: <https://www-chronicle-com. dartmouth.idm.oclc.org/article/the-shrinking-of-the-scholarly-ranks>. Accessed on: 2021 Feb. 16. 